\title{
Pre-Service English Teachers' Perceptions, Obstacles and Experiences When Teaching English in the EFL Context
}

\author{
Rashed Zannan Alghamdy ${ }^{1}$ \\ ${ }^{1}$ College of Education, Al-Baha University, Al-Baha, Saudi Arabia \\ Correspondence: Rashed Zannan Alghamdy. E-mail: rz000@hotmail.com
}

Received: May 23, $2018 \quad$ Accepted: June 4, $2018 \quad$ Online Published: July 27, 2018

doi:10.5539/ass.v14n8p102 URL: https://doi.org/10.5539/ass.v14n8p102

\begin{abstract}
This article has identified the opinions, perceptions، obstacles and experiences of the EFL pre-service English teacher who participated in a training program in EFL context. In this study, only qualitative data was gathered. The participants in this study were 7 pre-service English teachers aged 23-28 years, from seven boys' schools in Al-Baha city in Saudi Arabia. The researcher interviewed them at the end of the semester of the training program. The findings of this study were that some EFL pre-service English teachers felt that the training program enabled them to increase their confidence and social skills, enabling them to gain more experiences.

However, there were many disadvantages, barriers and obstacles to practicing pre-service teaching in the training program. These included: some EFL students were naughty and they caused problems in the classroom, the EFL students' English level was very weak such that they could not communicate in the language and even they also could not understand the teacher's instructions. Being in the training program, and studying at the college at the same time was very challenging for the pre-service English teachers. Also, some their main teachers were not willing to guide them. They were also often shy and embarrassed before the students. There were claims that the preparation book was difficult for most pre-service teachers to prepare. Most complained that they lacked the resources they required to prepare for their lessons.
\end{abstract}

Keywords: applied linguistic, teaching English as foreign language, pre-service English teachers, Saudi Arabia

\section{Introduction}

English teaching in Saudi Arabia began in 1930 when the ministry of education proposed it's application in teaching subjects like medicine, science, engineering, and aviation (Alabbad, 2009). Learning of this language was made compulsory and was to begin in the sixth to twelfth grade in public school. English lessons take place four times a week with each period lasting for 45 minutes. For each student to proceed to the next level, they must pass the English exam. They learn skills like speaking, writing, listening, reading, grammar and also vocabulary. The education system in Saudi occurs in five stages which include nursery, elementary, intermediate, high scool and university level (Alghamdi, 2008).

Al Shumaimeri (1999) claims that English is the only alien language taught in Saudi schools. English skills are below the required standard hence not satisfactory. Marks for most EFL learners are as low as $60-70 \%$ in the achievement test designed by the ministry of education. According to Al Shumaimeri (1999), research showed that the English language was only studied for the purpose of passing the final examination. It was crucial for the student to excel in both writing and grammar to pass the exam. The main reasons for poor performance in English as investigated by Alghamdi (2008), was due to insufficient teaching skills and methodology, poor selection of EFL program content and absence of learning motivation. Al Shammary (2005) showed that secondary schools students were not capable of using the language correctly due to the absence of incentives and encouragement and negative attitude towards EFL learning. At the age of 13-17 years, at the secondary level, the free education ends and students must enroll for higher education. They, at this stage need to demonstrate high English proficiency level. Unfortunately, not many can afford to speak the language fluently making it difficult to write a single paragraph correctly (Alghamdi, 2008).

According to Mason (2013), there is increased criticism and debate concerning teacher education. Globally, educators are focusing on quality teacher preparation through attracting, retaining and developing efficient teachers from 25 different countries as stated by $(\mathrm{OECD}, 2005)$. Findings show that there are three issues shared 
by these countries concerning preparation, skills, and knowledge of educators. Only a few teachers have the required competencies to meet the school requirement. Again, there is lack of a systematic orientation program. The traditional teacher education service is inadequate hence not effective. Boyle-Baise and McIntyre (2008) indicate that reduced preparation where schools are separated by theory or practice or where the connection is lacking in learning. In-service teachers, act as mental in teaching and field experiences (Mason, 2013). The study aims at identifying difficulties encountered recognition of better teaching practices to increase performance in schools.

In this study, the researcher tries to answer what the pre-service English teachers actually do in a new classroom, how they find the teaching in schools, what are the obstacles and difficulties that they encounter and how can they deal with them in a proper way. Moreover, this study is important to identify whether the EFL pre-service English teachers need more preparing program or they are ready to go to schools where they will get chance to practice teaching and their teaching level will gradually increase through the time.

\section{Purpose of the Study}

There is still not much known about what pre-service English teachers actually do in a new classroom and how they find the teaching in schools and what are the obstacles and difficulties that they encounter and how can they deal with them in a proper way. Furthermore, this study is important to identify whether the EFL pre-service English teachers need more preparing program or they are ready to go to schools but they need to get chance to practice teaching and their teaching level will gradually increase through the time.

\section{Methods}

\subsection{Participants}

The participants in this study were 7 pre-service English teachers, aged 23-28 years, in seven boys' schools in Al-Baha city in Saudi Arabia. The researcher interviewed them at the end of semester 1, 2017. The interview questions were designed by the researcher to identify how EFL pre-service teachers responded to their new experiences in teaching English in an EFL classroom environment. The pre-Service-English teachers' interviews were conducted individually and were audio-recorded by the researcher.

\subsection{Procedures}

Freebody (2003) argues that qualitative data in this study through semi-structured interviews give teachers opportunities to answer the posed questioned. The audio-taped interview rechecking was essential for accuracy. The analysis of presented data was through the inductive approach where transcription and coding helped to identify themes (Creswell, 2012). Data reviewing helped identify if the themes represented the interview data.

The researcher identified themes by keywords, phrases, and sentences as used in answering the questions. The researcher split the phrases and keywords, then pre-examined and categorized them in different themes formed during the analysis of interview data. By the help of the previous research and theoretical framework used in the same field, the researcher was able to group the data into seven key themes.

\section{Results and Discussion}

Seven pre-service English teachers were interviewed individually by the researcher at the end of first semester to get their opinions, thoughts and experiences in teaching the English language in an EFL Classroom. The interview was to gather data about the EFL pre-service English experiences and their perceptions about teaching English in EFL classroom, and the extent to which they believed they benefited from training teaching English in a classroom environment. Moreover, the interview investigated EFL teacher perceptions of the obstacles and difficulties that they encounter when teaching English in the EFL context. The researcher grouped the different themes that emerged from the interview data into seven main themes:

Embarrassment and shyness, preparation book, difficulty in speaking English, Lack of understanding English instructions, lack of enough available resources, academic achievements, and obstacles in training.

\subsection{Embarrassment and Shyness}

The first of the seven themes that emerged from the data was that embarrassment of EFL pre-service English teacher. Some English training teachers indicated that they were shy and embarrassed thus unable to effectively explain English concepts at first. One teacher commented, "I have faced shyness and embarrassment at the beginning of the term but over the time I feel more confidence". Another teacher added" "I have faced shyness and embarrassment at the beginning of the term but through time I feel more confident ". Another teacher indicated, "Definitely, I have felt scared and shy during the first 4 weeks of the training program" (1). Prisbell, (1991) points out that being shy can be a great challenge to anyone generally affecting their social lives. 
On the other hand, an English teacher highlighted that they were neither shy nor embarrassed during the whole training program. One teacher stated "I was not shy when I entered my class. I was so confident". Another teacher added, "I explained my English lessons normally, there was no embarrassment"

\subsection{The Preparation Book}

The second theme to emerge from the data was that the preparation book was not easy to prepare. Some teachers revealed "It was hard to prepare three different classes daily; it took so much time". Another teacher added "I faced a lot of difficulty in writing the preparation book at the beginning of the term: however, with time I got through it". A third teacher indicated, "It was the biggest problem that I faced during my training program".

On the other hand, some pre-service English teachers stated that there was no need to write preparation book on their own, instead, they copied it from ready materials of certified websites and CDs. One pre-service English teacher highlighted "I preferred to copy my preparation book rather than write it"

\subsection{Difficulty in Understanding and Speaking English}

Another theme that emerged from the data was difficulty in speaking English. Some teachers revealed that, "We live in an Arabic country and therefore our English is weak and we make many mistakes in the classroom when using the English language". Another teacher added "During the first 2 weeks, it was difficult to speak in English but over time, I have improved my spoken English. A third teacher indicated "It was hard to speak in English especially when the supervisor was in the classroom. Moreover, some pre-service English teachers revealed that the EFL students could not communicate in English and neither did they understand the teacher instructions inside the classroom. One teacher remarked "I noticed that students did not embrace communicating in English and that they hated it". Another teacher indicated, "It was so difficult to give instruction in English because the students did not understand English unless I translated it to Arabic." A third teacher indicated, "Students did not have tendency to practice the English language and they only understood instructions in Arabic only". Al-Shammary (2005) agrees with the findings when he claims that most students even after going through the EFL program for six years were not in a position to use the English language correctly.

\subsection{Inadequate Resources}

The fifth theme to emerge from the data is lack of enough resources inside the EFL classroom. Some teachers highlighted, "It was hard to use resource room in the school because many teachers preferred to use it and it was not enough for everyone". Another teacher commented "I suffered a lot to use of resources because not much was available". Some studies conducted in the field of technology use in Saudi context are limited and indicate only a restricted use of CALL in education in Saudi schools. Even in the few institutes that use CALL resources, there is either limited access to these resources or these resources are used with no adequate pedagogical understanding of CALL implementation (Alabbad, 2009).

On the other hand, some pre-service English teachers indicated that they could use technology and it was available all the time in the school. One teacher stated "the technology is available such as laptops, projectors, DVDs, CDs and smart-boards".

\subsection{Academic Achievement}

Most pre-service English teachers commented that the EFL level of English knowledge is low and that most students did not even know the alphabetical letters. One teacher stated that, "Students' levels are different; few students are good whereas many students cannot even say the alphabetical letters". Another teacher indicated "Students are so weak in English and cannot pronounce even one word correctly". Alghamdi (2008) states that most students can not only write a paragraph in English with so much difficulty but cannot express themselves fluently in the language. The author also highlights that the four main reasons behind poor results in the use of the English language include; poor teaching methods, inadequate professional skills in teachers, lack of motivation in the students, and a poor setting of the tests in the EFL program.

Some teachers stated that some students were naughty and they made problems the classroom especially when they knew that the teacher was in the training program. One pre-service teacher highlighted "Naughty students are the biggest problem for trainee teachers. For example students hurl bad words loudly and there is too much movement in the class". Another pre-service teacher stated that, "I am suffering a lot of naughty students and they make my classroom so boring". Pre-service English teachers also stated that the textbooks are difficult to the EFL students.

For example, one pre-service English teacher highlighted, "The textbooks are difficult especially for primary levels". A second pre-service English teacher said, "Textbooks are more developed now and they need more 
skills in critical thinking and other activities".

Alghamdi, 2008 highlights that the main reason for the low level of student achievement in learning English is poor selection of the contents of the EFL program. Some pre-service English teachers complained that the time and number of periods allocated for the subject are not sufficient to explain and present all lessons on the textbooks. One pre-service English teacher highlighted that the period numbers were few and not enough to cover all parts of the textbooks.

\subsection{Challenges in the Training Program}

Most pre-service English teachers highlighted that practice in the training program and studying some courses at the same time in the college was the hardest thing for them. One teacher stated that "it was so difficult to teach at school and attend some courses at the University". Also, a second teacher added, "It is necessary to practice training program in one semester and schedule studying some courses at the University for another semester". A third pre-service teacher complained that, "the trainee teachers should stay at the school all the time to gain more skills because attending the University for some courses while still teaching in the school for 2 hours or 2-3 days will not benefit the trainee and will affect his/her performance.

Some pre-service teachers also claimed that the principals and head teachers asked them to teach for more periods and also other subjects. One pre-service teacher stated, "The teacher in charge asked me to teach more classes and more periods than 8 hours per week". Some pre-service English teachers highlighted that the head teachers were not beneficial and they did not guide them .One teacher claimed, "My head teacher was so busy and he did not give me any attention". Another pre-service English teacher said, "The main English teacher has 24 periods per week so he is not available for me at any time". Some researchers have found that concerned guiding teachers are the most influential figures in the preparation of pre-service teachers (American Association of Colleges for Teacher Education, 1991). The results of the survey highlighted that many teachers would consider becoming more involved, if given the chance to attend regular meetings, guest teaching, teaching part-time, teaching full-time or participating in teacher-faculty exchanges (Mason, 2013).

Some pre-service English teacher claimed that classroom management skills are essential for every teacher and they need more workshops in how to manage and control the class. One teacher stated, "I don't have enough experience to manage my classroom". Another teacher confessed, "I cannot control naughty students and the school administration did not assist me".

\subsection{Advantages of the Training Program}

Many pre-service English teachers mentioned many advantages of the training program. Some pre-service English teachers highlighted that the training program enabled them to gain more experiences and learn how to deal with different issues at the school. One pre-service English teacher said, "I am now accustomed to the work at school and to the teacher, students, parents and the school administration."

Pre-service English teachers commented that the training program increased their confidence and social skills. One teacher remarked, "It was an amazing semester, I feel more confident and I can present my lessons easily". Also, another pre-service English teacher added "communication skills are very important especially at the school, during my training program I gained many social skills such as talking before people".

\section{Conclusion}

This article has identified the opinions, perceptions and experiences of the EFL pre-service English teachers who participated in the training program in EFL context in Saudi government schools.

To sum up, some EFL pre-service English teachers found that training program enabled them to increase their confidence and social skills, enable them to gain more experiences.

However, there were many drawbacks, barriers and obstacles to practicing teaching in the training program. These included: some EFL students being naughty and making noise in the classroom, practicing in the training program while also studying some courses at the college, the main teachers not being beneficial and not guiding them, shyness and embarrassment, the preparation book being difficult to prepare and having inadequate available resources.

\section{References}

Alabbad, A. M. (2009). Introducing constructivism and computer-assisted language learning (CALL) into traditional EFL programs in Saudi Arabia (Unpublished doctoral dissertation). University of Queensland, St. Lucia, Queensland. 
Alghamdi, R. (2008). Reasons of low achievement level of intermediate pupils in learning English from the viewpoints of academic teachers, teachers, and supervisors' in Makkah and Taif (Unpublished master's thesis). Umm Al-Qura University. In Arabic.

Al-Shammary, E. A. S. (2005). A study of motivation in the learning of English as a foreign language in intermediate and secondary schools in Saudi Arabia (Unpublished doctoral thesis). Indiana University, Ann Arbour, MI.

Al-Shumaimeri, Y. A. N. (1999). Saudi students' perceptions of their textbook: English for Saudi Arabia, (EFSA), secondary year one (Unpublished master's thesis). University of Leeds, Leeds, UK.

American Association of Colleges for Teacher Education (1991). RATE IV: Teaching teachers: Facts \& figures. Washington, DC: Author.

Boyle-Baise, M., \& McIntyre, D. J. (2008). What kind of experience? Preparing teachers in PDS or community settings. In M. Cochran-Smith, S. Feiman-

Creswell, J. W. (2012). Educational research: Planning, conducting, and evaluating quantitative and qualitative research (4th ed.). Boston, MA: Pearson Education Inc.

Freebody, P. (2003). Qualitative research in education: interaction and practice. London: SAGE Publications.

Mason, K. O. (2013). Teacher involvement in pre-service teacher education. Teachers and Teaching, 19(5), 559-574. https://doi.org/10.1080/13540602.2013.827366

Organisation for Economic Co-operation and Development (OECD) (2005). Teachers matter: Attracting, developing, and retaining effective teachers. Paris. https://doi.org/10.4135/9781849209670

Prisbell, M. (1991). Shyness and self-reported competence. Communication Research Reports, 8(2), 141-150. https://doi.org/10.1080/08824099109359886

\section{Copyrights}

Copyright for this article is retained by the author(s), with first publication rights granted to the journal.

This is an open-access article distributed under the terms and conditions of the Creative Commons Attribution license (http://creativecommons.org/licenses/by/4.0/). 